T. Crossley, M. Jametti

Pension benefit insurance and pension plan portfolio choice

Quaderno N. 08-09

Decanato della Facoltà di Scienze economiche

Via G. Buffi, $13 \mathrm{CH}-6900$ Lugano 


\title{
Pension Benefit Insurance and Pension Plan Portfolio Choice*
}

\author{
Thomas Crossley ${ }^{\dagger}$ \\ University of Cambridge, \\ IFS, London, \\ and \\ SEDAP Research Program
}

\author{
Mario Jametti ${ }^{\ddagger}$ \\ University of Lugano, Switzerland, \\ York University, Toronto, \\ SEDAP Research Program, \\ and
}

November 2008

\begin{abstract}
Pension benefit guarantee policies have been introduced in several countries to protect private pension plan members from the loss of income that would occur if a plan was underfunded when the sponsoring firm terminates a plan. Most of these public insurance schemes face financial difficulty and consequently policy reforms are being discussed or implemented. Economic theory suggests that such schemes will face moral hazard and adverse selection problems. In this note we test a specific theoretical prediction: insured plans will invest more heavily in risky assets. Our test exploits differences in insurance arrangements across Canadian jurisdictions. We find that insured plans invest about 5 percent more in equities than do similar plans without benefit guarantees.
\end{abstract}

JEL Classification: G23, G11, C21

Keywords: Pensions, benefit guarantee, moral hazard

${ }^{*}$ We thank Sule Alan, Monika Bütler, Sylvie Michaud, Karen Mihorean, Michel Palardy, Tarmo Valkonen, Catherine Van Rompaey, and seminar participants at the Internatinal Institute of Public Finance (Maastricht University, 2008), York University and the University of Lugano for helpful comments. Special thanks go to the staff of the Pension and Wealth Section of Statistics Canada for their efforts in constucting the data and to Steve Bonnar for helping us to understand some of the finer points of pension regulation. Financial support from the SEDAP Research Program centered at McMaster University, from Statistics Canada and from York University is also gratefully acknowledged. The interpretation of the data given in this paper should be attributed only to the authors. We are also solely responsible for any remaining errors or omissions.

${ }^{\dagger}$ Faculty of Economics, University of Cambridge, Sidgwick Avenue, Cambridge, UK, CB3 9DD; e-mail: Thomas.Crossley@econ.cam.ac.uk.

${ }^{\ddagger}$ Corresponding author: Institute for Microeconomics and Public Economics (MecoP), University of Lugano, Via G. Buffi 6, 6904 Lugano, Switzerland; e-mail: mario.jametti@lu.unisi.ch. 


\section{Introduction}

In many developed countries, underfunding of Defined Benefit (DB) pension plans has become a significant concern. Underfunding is a situation where the net present value of liabilities is greater than that of assets in a pension plan. Regulatory reports show significant and alarming degrees of underfunding of employee-sponsored pension plans (see, e.g. Wilcox, 2006, for a discussion of the situation in the U.S.). The central concern with underfunding is, of course, the possibility that a plan will have insufficient assets to cover its liabilities at the moment the sponsoring firm is forced to terminate the DB plan. ${ }^{1} \mathrm{~A}$ reduction in retirement income of plan members may result. Several countries have adopted insurance mechanisms to limit the losses of plan members in such situations. Examples are the Pension Benefit Guaranty Corporation (PBGC) in the U.S., the Pension Benefit Guarantee Fund (PBGF) in Ontario, Canada, and the Pension Protection Fund (PPF) in the UK. However, most such benefit guarantee schemes are now in financial difficulty. For example, Brown (2008) reports that the U.S. PBGC had a deficit of almost $\$ 19$ billion in 2006. In the U.S. case, persistent financial deficits led to widespread discussions of possible reforms of the pension benefit guarantee and to the implementation of the Pension Protection Act in 2006.

As with most insurance schemes, pension benefit guarantees can suffer from problems of moral hazard and adverse selection (Brown, 2008; Jametti, 2008). The literature contains a number of predications with respect to the effects of insurance (or guarantees) on plan behavior. These include: i) increases in the level of underfunding (Cooper and Ross, 2003); ii) increases in the risk exposure of the plan's portfolio (Sharpe, 1976; Bodie, 1990; Cooper and Ross, 2003); and iii) increases in retiree benefits among plans with a higher default risk (Niehaus, 1990). While these effects have been identified theoretically, little work has been done to assess their empirical relevance. Quantifying the actual magnitude of these moral hazard effects is an important input to the policy discussion around the reform of private pension systems.

The contribution of this paper is to use newly available data and cross-jurisdiction variation in pension guarantee arrangements to test one specific prediction that emerges

\footnotetext{
${ }^{1}$ A termination of a plan might occur, for example, upon bankruptcy of the sponsoring firm.
} 
from the theoretical literature. In particular, we investigate empirically whether DB pension plans with benefit insurance hold riskier portfolios. To do so, we use a newly constructed Canadian data set which contains information on plan characteristics (including jurisdiction of registration) and their liabilities, total assets, and portfolio allocations.

Identifying the effect of benefit insurance with U.S. data is challenging because the PBGC is a federal program, introduced for all single employer DB plans in 1974. This means that only time series variation in guarantee arrangements - the introduction and reform of the program - is available for study. Moreover, the temporal variation generated by recent reforms is confounded, because other regulatory changes (notably minimum funding standards) were introduced at the same time. ${ }^{2}$ The analysis of pension benefit guarantee systems in most other countries faces similar problems. Consequently, identifying additional sources of variation in guarantee arrangements seems important.

DB plans in Canada are generally under the domain of the financial market supervisors of the Province where they are registered. ${ }^{3}$ Plans with members in several provinces are registered with the jurisdiction with most members. Currently, only the province of Ontario has (in 1980) introduced benefit insurance, the PBGF, inspired by its U.S. counterpart. The administrator of a terminated pension plan applies to the PBGF for funding of insured pensions. ${ }^{4}$ Thus comparison of pension plans in Ontario with similar pension plans registered in other provinces provides an alternative source of variation with which to asses the moral hazard effects of pension guarantees.

Under the PBGF, pensions are guaranteed up to Can $\$ 1000$ per month per member. The maximum funding per member has not changed since inception, hence the real value of benefit coverage has declined over time. The PBGF, while an account of the Provincial government, is intended to be financially independent, and funded through levies on all registered DB plans. Initially the premium rate was a fixed amount per member. In 1990 an

\footnotetext{
${ }^{2}$ This is illustrated in previous empirical analysis on the effect of the Employment Retirement Security Act (ERISA) on investment decisions of DB pension plans by Cummins et. al. (1980) and Cummins and Outreville (1984). Both papers mention Sharpe's (1976) prediction but consider other ERISA provisions, such as the minimum funding standard, to be more important. Incidentally, Cummins and Outreville (1984) find a move out of (riskier) equities with the introduction of ERISA.

${ }^{3}$ The most important provincial supervisor is the Financial Services Commission (FSCO) in Ontario, where almost $50 \%$ of plans are registered. The small province of Prince Edward Island does not have a regulatory authority. Some industrial sectors (e.g. interprovincial transportation, banks) are under federal supervision by the Office of the Superintendent of Financial Institutions (OFSI).

${ }^{4}$ As such, the PBGF, contrary to the U.S. insurance, does not administrate the insured plans.
} 
additional variable premium rate was introduced depending on the degree of underfunding of the plan. The current financial situation of the PBGF is far from secure. In particular, there is widespread agreement that the insurance would not survive the consequences of bankruptcy of one of the big employers in Ontario with a DB plan (such as one of the two big steel producers). There is less consensus on whether the guarantee fund is implicitly backed by the government. Reform of the system, including the PBGF, is currently being discussed by an expert commission set up by the provincial government.

Nielson and Chan (2006) also exploit the comparison between Ontario and other Canadian provinces. However, the data that we use, which is described below, is newly available. Nielson and Chan show that pension plans with benefit insurance (in Ontario) have less assets per member than those without (in other provinces). This result suggests that insurance exacerbates underfunding (as theory would suggest), but because Nielson and Chan do not have data on liabilities (only assets), they can not examine underfunding directly. Nor can they look at the portfolio allocation of plans, which is our focus. Because underfunding has been penalized in the premiums that plan sponsors (firms) must pay to PBGF since 1990, one would expect moral hazard problems to play out more significantly on other, nonrisk-rated (ie., non-priced) margins. It is exactly such a margin (the riskiness of portfolios) that we examine.

\section{Data and methods}

Statistics Canada has two surveys related to private pensions: the biannual Census of Trusteed Pension Funds (TPF) and the annual Pension Plans in Canada (PPIC) survey. TPF collects information on pension assets and portfolio allocation directly from the sponsoring firms or their asset managers, while PPIC is collected from the regulatory authorities and includes aspects of plan characteristics, jurisdiction of registration, membership and actuarial evaluations. ${ }^{5}$ We work with a newly available data set which merges information from these two sources. (See Palardy and Van Rompaey, 2008, for a description of the linking of the two surveys.) We concentrate on private sector DB plans. Additionally, data

\footnotetext{
${ }^{5}$ Note that PPIC includes all types of pension plans, while TPF, as the name suggests, only considers plans held in trust.
} 
on portfolio allocation is only collected for plans with more than Can $\$ 10 \mathrm{~m}$ in assets. We currently have four waves of data over the period 1998 to 2004 . There are 1378 plans in our sample. The panel is unbalanced, and contains 4400 plan-year observations.

Most DB plans invest assets under a trust fund agreement. Some plans pool assets together in what is called a Master Trust Fund (MT). Investment decision of MT's are taken jointly for all assets within it. Note that an MT is not restricted to contain only DB plans, and it can include plans registered in several Provinces. However, regulation is always at the plan level and MT's have to comply with the respective legislation for each plan. The unit of observation in TPF is the fund, while it is the plan in PPIC. We conduct our analysis at a plan level. Where plans belong to a MT we assign all assets (and hence the portfolio shares) to every plan within the MT. As a robustness check, we have also pursued an alternative strategy of aggregating plan characteristics to the MT level, and conducting the analysis with the MT as the unit of observation. Results from this analysis are quantitatively similar to the ones we report below and are available from the authors on request.

Our empirical test is based on regressions of the following form:

$$
s_{i j t}^{k}=\mathbf{X}_{i j t} \boldsymbol{\beta}+\gamma I n s_{j}+u_{i j t},
$$

where $s_{i j t}^{k}$ is the share of asset $k$ of plan $i$, registered in jurisdiction $j$, at time $t . \mathbf{X}_{i j t}$ is a set of control variables including plan and province specific variables as well as year effects. We estimate the above equation for two assets: equity $(e q)$ and bonds $(b d)$.

The dependent variable $s_{i j t}^{e q}$ is defined as the share of assets invested in equity measured at market value and including investment in pooled equity instruments. ${ }^{6}$ Similarly, $s_{i j t}^{b d}$ is defined as the share of portfolio assets invested in bonds, including pooled bond instruments. As Table 1 indicates, the mean equity share per plan is around $41 \%$, with an average of $34 \%$ invested in bonds. Hence these two asset categories constitute by far the most important financial instruments used by pension plans. Note that both for equity as for bonds there is a wide range of individual share values, including, in both cases, shares of zero. The

\footnotetext{
${ }^{6}$ Equity investment includes Canadian, US and Foreign stocks as well as pooled equity. Note that survey respondents in principle can distinguish between pooled equity and pooled bond instruments. We do not know to what extent pooled investments that include non-equity assets are reported within pooled equity.
} 
lower panel of Table 1 indicates average share values for plans with and without benefit guarantee. Plans without insurance invest $39.4 \%$ in equity, while plans with insurance invest $41.5 \%$. The raw mean difference across groups is thus $2.1 \%$. Correspondingly, plans without insurance invest, on average, $1.3 \%$ more in bonds.

Our main variable, $I n s_{j}$, represents whether a plan possesses a benefit guarantee insurance or not. Slightly more than $50 \%$ of all plans in the sample are covered by insurance. The prediction that plans with insurance have an incentive to hold riskier portfolios implies that $\gamma>0$ in the equity regression $\left(s_{i j t}^{e q}\right)$ and $\gamma<0$ in the bond regression $\left(s_{i j t}^{b d}\right)$.

We include a number of plan characteristics to capture other determinants of investment behavior. We include variables for total assets and number of members. Different investment opportunities might arise for larger plans. For example, smaller plans might not have the financial capacity for direct international equity investments. Similarly, the share of inactive (retired) members is likely to influence portfolio allocation. "Mature" plans (with higher share of inactive members) might use a more conservative investment strategy. Additionally, we include dummy variables for compulsory contributions by members and a dummy variable indicating funds that belong to a Master Trust. The average plan has $\$ 410 \mathrm{~m}$ in assets and around 1200 members. A third of all members are retired, $64 \%$ of plans are within an MT and 53\% require employees to contribute. The province specific macro variables are growth, inflation and employment rates to control for the overall provincial economic environment. Finally, time effects capture variations in stock market returns. ${ }^{7}$ Table 1 presents summary statistics for the plan level dataset. We also present summary statistics separated for plans with and without insurance.

The identifying assumption we must make, of course, is that, conditional on the controls just described, plans from other provinces behave as Ontario plans would behave in the absence of the pension guarantee. That is, with the currently available data we have only cross-sectional variation, and cannot allow for unobserved provincial differences. While it would be preferable to have both temporal and jurisdictional variation in policy (to allow a 'difference-in-difference' design) we believe that the Canadian jurisdictional variation provides a very useful compliment to the purely temporal variation available in the U.S.

\footnotetext{
${ }^{7}$ Thus we implicitly make the assumption that pension plans across the country have access to the same financial markets.
} 
and other countries. We have investigated whether other differences, particularly in pension regulation, between Ontario and other Canadian Provinces may confound our estimation strategy. Two potential differences are (i) Ontario is unique in requiring the funding of "grow in" benefits (benefits which members with sufficient service are entitled to if the plan is wound up - benefits they would have "grown into" had the plan continued); (ii) Ontario has a fair number of union negotiated plans which are flat dollar (rather than final pay) plans. Both issues will make the solvency liability larger relative to going concern liability, and raise the risk (from the sponsors point of view) of being required to make additional contributions. The sponsor may, in turn, choose to reduce risk by investing more in bonds and in particular long-duration bonds. Thus the potential confounds which we have been able to identify would tend to bias our empirical strategy against finding evidence of moral hazard.

In our first pass at the data, we estimate equation [1] for both equities and bonds with standard errors clustered at the Province level to take into account the higher level of aggregation of our main variable (see Moulton, 1990, for a discussion). We then perform a series of robustness checks. First, we apply Tobit estimation with clustered standard errors, since a significant number of observations report $s_{i j t}^{k}=0$. Second, Donald and Lang (2007) show that standard asymptotic inference might not apply if some variables are fixed within groups and their number is small. To address this, we follow a two-stage procedure, ${ }^{8}$ first regressing the dependent variable $\left(s_{i j t}^{k}\right)$ on plan characteristics and a full set of provinceyear interactions. In the second stage we use the $(4 \times 10=40)$ interaction coefficients as the dependent variable and regress them on a constant, year effects and $I n s_{j}$. Additionally, we add the province-year specific variables. In the second stage we use weights inversely proportional to the number of plans.

\section{Results}

Results are presented in Table 2. For our equity regressions, the results vary little across specification. The range of coefficients on insurance is between 0.021 and 0.027 . This implies that plans benefiting from insurance invest, ceteris paribus, from 2.1 to 2.7 percentage points

\footnotetext{
${ }^{8}$ Baker and Milligan (2008) use a similar approach to study the effect of maternity leave extensions.
} 
more in riskier equities. At the mean portfolio shares, this estimate implies an increase in equity holdings of $5.4 \%(=0.022 / 0.405)$. Note that all estimates of the effect of insurance are statistically significant at least at the $10 \%$ level except for column (1a). The other coefficients are in line with expectations. Larger plans, in terms of assets, invest a higher share in equities. So do plans that pool their assets within a Master Trust.

The coefficient on insurance is large. To put the effect of insurance in perspective, note that it would require an increase in assets of 2.3 billion Can $\$$ to obtain the same increase in the share of equity; this is more than five times the assets of the average plan. ${ }^{9}$

We obtain less precise results for the bond regression with only one coefficient significant at the $10 \%$ level (column 3b). Nevertheless the range of coefficients is again fairly narrow between -0.017 and -0.010. Plans with benefit guarantees hold between 1 and 1.7 percentage points less of their portfolio in bonds.

\section{Conclusion}

Pension benefit guarantee mechanisms are currently the object of much policy discussion and concern, due to the fact that many of these institutions suffer from large financial deficits and are backed (at least implicitly) by the government and, in last instance, the taxpayer. Of particular concern is the possibility these public insurance programs suffer from moral hazard (on the part of the firms which sponsor insured plans.) We test empirically for a specific aspect of moral hazard that is predicted by theoretical models of pension benefit guarantees: pension plans with this kind of insurance will hold riskier investment portfolios. Our test exploits the institutional setting in Canada where only one province (Ontario) has insurance, while the others do not. Using a dataset that covers the period 1998 to 2004 we find that plans with benefit insurance invest 2.2 percentage points more in equities than similar uninsured plans. Evaluated at the means of our data this implies that insured plans hold about 5\% more in equities. The result is statistically and economically significant and quite robust. Although the variation that our test exploits is one-dimensional (cross-jurisdiction, but not time), we have considered potential

\footnotetext{
${ }^{9}$ This calculation is based on the OLS coefficient in column (1), however, the magnitudes vary little across the different estimation methods.
} 
confounders and argue that this source of variation is the cleanest comparison currently available. Moreover, the key potential confounders which we were able to identify would, if important, bias our estimation strategy against finding a moral hazard effect. Thus our results, in conjunction with the results of Nielson and Chan (2007), constitute significant evidence that pension benefit guarantees do suffer from moral hazard problems. At least until such time as new data makes further comparisons possible, policy makers will want to pay attention to this line of evidence.

The data on which our estimates are based is currently being extended backwards in time and, in the future, this will allow for further interesting research. In particular, it would be interesting to examine the effect the 1990 introduction of higher premiums for underfunded plans. 


\section{References}

[1] Baker, M. and K. Milligan, 2008, Evidence from maternity leave expansions of the impact of maternal care on early child development, NBER Working Paper 13826.

[2] Bodie, Z., 1990, Pension funds and financial innovation, Financial Management 19(3), $11-22$.

[3] Brown, J.R., 2008, Guaranteed trouble: the economic effects of the pension benefit guaranty corporation, Journal of Economic Perspectives 22(1), 177-198.

[4] Cooper, R.W. and T.W. Ross, 2003, Protecting underfunded pensions: the role of guarantee funds, Journal of Pension Economics and Finance 2(3), 247-272.

[5] Cummins, J.D. and J.F. Outreville, 1984, The portfolio behaviour of pension funds in the US: an econometric analysis of changes since the new regulation of 1974, Applied Economics 16, 687-701.

[6] Cummins, J.D., J.R. Percival, R. Westerfield. and J.G. Ramage, 1980, Effects of ERISA on the investment policies of private pension plans: survey evidence, Journal of Risk and Insurance 47(3), 447-476.

[7] Donald, F.G. and K. Lang, 2007, Inference with difference-in-differences and other panel data, Review of Economics and Statistics 89(2), 221-233.

[8] Jametti, M., forthcoming, Underfunding of Defined Benefit pension plans and benefit guarantee insurance - an overview of theory and evidence, Canadian Public Policy.

[9] Moulton, B.R., 1990, An illustration of a pitfall in estimating the effects of aggregate variables in micro units, Review of Economics and Statistics 72(2), 334-338.

[10] Nielson, N.L. and D.K.W. Chan, 2007, Private pensions and government guarantees: clues from Canada, Journal of Pension Economics and Finance 6(1), 45-66.

[11] Palardy, M. and C. Van Rompaey, 2008, A micro-based measurement framework for Canadian pensions, Paper prepared for the 30th General Conference of the International Association for Research in Income and Wealth.

[12] Sharpe, W. F., 1976, Corporate pension funding policy, Journal of Financial Economics 3, 183-193.

[13] Wilcox, D. W., 2006, Reforming the Defined-Benefit pension system, Brooking Papers on Economic Activity 2006(1), 235-304. 
Table 1: Descriptive Statistics

\begin{tabular}{|c|c|c|c|c|}
\hline & Mean & Std. Dev. & Min. & Max. \\
\hline \multicolumn{5}{|l|}{ All data (4440 obs.) } \\
\hline Share of equity & 0.405 & 0.191 & 0 & 1 \\
\hline Share of bonds & 0.338 & 0.155 & 0 & 1 \\
\hline Insurance & 0.511 & 0.500 & 0 & 1 \\
\hline Assets $^{1}$ & 0.411 & 1.181 & 0.009 & 13 \\
\hline Members $^{1}$ & 0.118 & 0.555 & 0.000 & 14 \\
\hline Share of inactive members & 0.332 & 0.226 & 0 & 1 \\
\hline Master Trust Fund & 0.644 & 0.479 & 0 & 1 \\
\hline Contribution & 0.537 & 0.499 & 0 & 1 \\
\hline GDP growth & 0.037 & 0.024 & -0.037 & 0.196 \\
\hline Inflation & 0.020 & 0.007 & 0.002 & 0.035 \\
\hline Employment share & 0.604 & 0.022 & 0.475 & 0.667 \\
\hline \multicolumn{5}{|l|}{ Insurance = 0 (2169 obs) } \\
\hline Share of equity & 0.394 & 0.195 & 0 & 1 \\
\hline Share of bonds & 0.344 & 0.166 & 0 & 1 \\
\hline Assets $^{1}$ & 0.458 & 1.421 & 0.009 & 13 \\
\hline Members $^{1}$ & 0.138 & 0.624 & 0.000 & 13 \\
\hline Share of inactive members & 0.343 & 0.217 & 0 & 1 \\
\hline Master Trust Fund & 0.603 & 0.489 & 0 & 1 \\
\hline Contribution & 0.441 & 0.497 & 0 & 1 \\
\hline \multicolumn{5}{|l|}{ Insurance = 1 (2271 obs.) } \\
\hline Share of equity & 0.415 & 0.187 & 0 & 1 \\
\hline Share of bonds & 0.332 & 0.144 & 0 & 1 \\
\hline Assets $^{1}$ & 0.365 & 0.890 & 0.009 & 12 \\
\hline Members $^{1}$ & 0.098 & 0.480 & 0.000 & 14 \\
\hline Share of inactive members & 0.322 & 0.234 & 0 & 1 \\
\hline Master Trust Fund & 0.683 & 0.465 & 0 & 1 \\
\hline Contribution & 0.628 & 0.483 & 0 & 1 \\
\hline
\end{tabular}


Table 2: Estimation Results

\begin{tabular}{|c|c|c|c|c|c|c|}
\hline & (1a) & $(\mathbf{( 1 b )}$ & 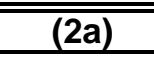 & $\overline{(2 b)}$ & 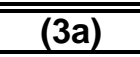 & 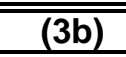 \\
\hline \multicolumn{7}{|c|}{ Dependent Variable: Share of equity: } \\
\hline Insurance & $\begin{array}{c}0.024 \\
(0.014)\end{array}$ & $\begin{array}{l}0.022^{\star} \\
(0.010)\end{array}$ & $\begin{array}{c}0.027^{*} \\
(0.016)\end{array}$ & $\begin{array}{l}0.024^{\star *} \\
(0.012)\end{array}$ & $\begin{array}{l}0.023^{\star *} \\
(0.011)\end{array}$ & $\begin{array}{c}0.021^{*} \\
(0.012)\end{array}$ \\
\hline Assets & $\begin{array}{l}0.010^{* *} \\
(0.003)\end{array}$ & $\begin{array}{l}0.009^{* *} \\
(0.003)\end{array}$ & $\begin{array}{c}0.010^{* * *} \\
(0.003)\end{array}$ & $\begin{array}{c}0.010^{* * *} \\
(0.003)\end{array}$ & & \\
\hline Members & $\begin{array}{l}-0.005 \\
(0.005)\end{array}$ & $\begin{array}{l}-0.005 \\
(0.005)\end{array}$ & $\begin{array}{l}-0.004 \\
(0.006)\end{array}$ & $\begin{array}{l}-0.004 \\
(0.006)\end{array}$ & & \\
\hline Share of inactive members & $\begin{array}{l}-0.018 \\
(0.021)\end{array}$ & $\begin{array}{l}-0.018 \\
(0.021)\end{array}$ & $\begin{array}{l}-0.013 \\
(0.022)\end{array}$ & $\begin{array}{c}-0.013 \\
(0.022)\end{array}$ & & \\
\hline Master Trust Fund & $\begin{array}{c}0.041^{\star * *} \\
(0.010)\end{array}$ & $\begin{array}{c}0.040^{* * *} \\
(0.010)\end{array}$ & $\begin{array}{c}0.049^{* * *} \\
(0.010)\end{array}$ & $\begin{array}{c}0.048^{* * *} \\
(0.010)\end{array}$ & & \\
\hline Contribution & $\begin{array}{l}-0.033 \\
(0.028)\end{array}$ & $\begin{array}{l}-0.033 \\
(0.028)\end{array}$ & $\begin{array}{l}-0.035 \\
(0.029)\end{array}$ & $\begin{array}{l}-0.035 \\
(0.029)\end{array}$ & & \\
\hline GDP growth & & $\begin{array}{l}-0.420^{*} \\
(0.201)\end{array}$ & & $\begin{array}{c}-0.439^{* *} \\
(0.220)\end{array}$ & & $\begin{array}{l}-0.442 \\
(0.269)\end{array}$ \\
\hline Inflation & & $\begin{array}{c}0.650 \\
(1.653)\end{array}$ & & $\begin{array}{c}0.658 \\
(1.791)\end{array}$ & & $\begin{array}{c}0.711 \\
(1.847)\end{array}$ \\
\hline Employment share & & $\begin{array}{c}0.202 \\
(0.352)\end{array}$ & & $\begin{array}{c}0.228 \\
(0.376)\end{array}$ & & $\begin{array}{r}0.167 \\
(0.303)\end{array}$ \\
\hline Number of observations & 4440 & 4440 & 4440 & 4440 & 40 & 40 \\
\hline $\mathrm{R}^{2}$ & 0.03 & 0.04 & & & 0.20 & 0.28 \\
\hline \multicolumn{7}{|c|}{ Dependent Variable: Share of bonds: } \\
\hline Insurance & $\begin{array}{l}-0.010 \\
(0.011)\end{array}$ & $\begin{array}{l}-0.016 \\
(0.011)\end{array}$ & $\begin{array}{l}-0.016 \\
(0.013)\end{array}$ & $\begin{array}{c}-0.017 \\
(0.013)\end{array}$ & $\begin{array}{l}-0.010 \\
(0.009)\end{array}$ & $\begin{array}{l}-0.017^{\star} \\
(0.009)\end{array}$ \\
\hline Assets & $\begin{array}{c}0.000 \\
(0.002)\end{array}$ & $\begin{array}{l}-0.001 \\
(0.002)\end{array}$ & $\begin{array}{c}0.000 \\
(0.002)\end{array}$ & $\begin{array}{c}-0.001 \\
(0.002)\end{array}$ & & \\
\hline Members & $\begin{array}{c}0.005 \\
(0.005)\end{array}$ & $\begin{array}{c}0.005 \\
(0.005)\end{array}$ & $\begin{array}{c}0.007 \\
(0.005)\end{array}$ & $\begin{array}{c}0.005 \\
(0.006)\end{array}$ & & \\
\hline Share of inactive members & $\begin{array}{l}0.071^{* *} \\
(0.026)\end{array}$ & $\begin{array}{l}0.072^{* *} \\
(0.026)\end{array}$ & $\begin{array}{c}0.078^{* * *} \\
(0.027)\end{array}$ & $\begin{array}{c}0.076^{* * *} \\
(0.027)\end{array}$ & & \\
\hline Master Trust Fund & $\begin{array}{l}0.028^{\star *} \\
(0.012)\end{array}$ & $\begin{array}{l}0.027^{\star *} \\
(0.012)\end{array}$ & $\begin{array}{c}0.035^{\star * \star} \\
(0.012)\end{array}$ & $\begin{array}{c}0.038^{* * *} \\
(0.011)\end{array}$ & & \\
\hline Contribution & $\begin{array}{c}-0.016^{* *} \\
(0.007)\end{array}$ & $\begin{array}{c}-0.017^{* *} \\
(0.007)\end{array}$ & $\begin{array}{c}-0.019^{\star *} \\
(0.008)\end{array}$ & $\begin{array}{c}-0.020^{* *} \\
(0.008)\end{array}$ & & \\
\hline GDP growth & & $\begin{array}{l}-0.195 \\
(0.137)\end{array}$ & $\begin{array}{l}-0.240 \\
(0.161)\end{array}$ & $\begin{array}{l}-0.240 \\
(0.163)\end{array}$ & & $\begin{array}{l}-0.207 \\
(0.201)\end{array}$ \\
\hline Inflation & & $\begin{array}{l}-2.084^{*} \\
(1.110)\end{array}$ & $\begin{array}{l}-2.262^{*} \\
(1.235)\end{array}$ & $\begin{array}{l}-2.059^{*} \\
(1.203)\end{array}$ & & $\begin{array}{l}-2.061 \\
(1.382)\end{array}$ \\
\hline Employment share & & $\begin{array}{c}0.352 \\
(0.258)\end{array}$ & $\begin{array}{c}0.384 \\
(0.295)\end{array}$ & $\begin{array}{c}0.396 \\
(0.311)\end{array}$ & & $\begin{array}{c}0.335 \\
(0.226)\end{array}$ \\
\hline $\begin{array}{l}\text { Number of observations } \\
R^{2}\end{array}$ & $\begin{array}{l}4440 \\
0.03\end{array}$ & $\begin{array}{l}4440 \\
0.03\end{array}$ & 4440 & 4440 & $\begin{array}{c}40 \\
0.30\end{array}$ & $\begin{array}{c}40 \\
0.38\end{array}$ \\
\hline
\end{tabular}

Notes: Constant and year effects included in all regressions.

(1) OLS with standard errors clustered at the Province level

(2) Tobit regression with standard errors clustered at the Province level.

(3) Second stage weighted least squares regression. Weights are inversely proportional to number of plans. All first stage regressions include plan level variables and a full set of province-year interactions (not shown). 


\section{QUADERNI DELLA FACOLTÀ}

I quaderni sono richiedibili (nell'edizione a stampa) alla Biblioteca universitaria di Lugano via G. Buffi 13 CH 6900 Lugano

e-mail: biblioteca@lu.unisi.ch

The working papers (printed version) may be obtained by contacting the Biblioteca universitaria di Lugano

via G. Buffi 13 CH 6900 Lugano

e-mail: biblioteca@lu.unisi.ch

Quaderno n. 98-01

P. Balestra, Efficient (and parsimonious) estimation of structural dynamic error component models

Quaderno n. 99-01

M. Filippini, Cost and scale efficiency in the nursing home sector : evidence from Switzerland

Quaderno n. 99-02

L. Bernardi, I sistemi tributari di oggi : da dove vengono e dove vanno

Quaderno n. 99-03

L.L. Pasinetti, Economic theory and technical progress

Quaderno n. 99-04

G. Barone-Adesi, K. Giannopoulos, L. Vosper, VaR without correlations for portfolios of derivative securities

Quaderno n. 99-05

G. Barone-Adesi, Y. Kim, Incomplete information and the closed-end fund discount

Quaderno n. 99-06

G. Barone-Adesi, W. Allegretto, E. Dinenis, G. Sorwar, Valuation of derivatives based on CKLS interest rate models

Quaderno n. 99-07

M. Filippini, R. Maggi, J. Mägerle, Skalenerträge und optimale Betriebsgrösse bei den schweizerische Privatbahnen

Quaderno n. 99-08

E. Ronchetti, F. Trojani, Robust inference with GMM estimators

Quaderno n. 99-09

G.P. Torricelli, I cambiamenti strutturali dello sviluppo urbano e regionale in Svizzera e nel Ticino sulla base dei dati dei censimenti federali delle aziende 1985, 1991 e 1995 
Quaderno n. 00-01

E. Barone, G. Barone-Adesi, R. Masera, Requisiti patrimoniali, adeguatezza del capitale e gestione del rischio

Quaderno n. 00-02

G. Barone-Adesi, Does volatility pay?

Quaderno n. 00-03

G. Barone-Adesi, Y. Kim, Incomplete information and the closed-end fund discount

Quaderno n. 00-04

R. Ineichen, Dadi, astragali e gli inizi del calcolo delle probabilità

Quaderno n. 00-05

W. Allegretto, G. Barone-Adesi, E. Dinenis, Y. Lin, G. Sorwar, A new approach to check the free boundary of single factor interest rate put option

Quaderno n. 00-06

G.D.Marangoni, The Leontief Model and Economic Theory

Quaderno n. 00-07

B. Antonioli, R, Fazioli, M. Filippini, Il servizio di igiene urbana italiano tra concorrenza e monopolio

Quaderno n. 00-08

L. Crivelli, M. Filippini, D. Lunati. Dimensione ottima degli ospedali in uno Stato federale

Quaderno n. 00-09

L. Buchli, M. Filippini, Estimating the benefits of low flow alleviation in rivers: the case of the Ticino River

Quaderno n. 00-10

L. Bernardi, Fiscalità pubblica centralizzata e federale: aspetti generali e il caso italiano attuale

Quaderno n. 00-11

M. Alderighi, R. Maggi, Adoption and use of new information technology

Quaderno n. 00-12

F. Rossera, The use of log-linear models in transport economics: the problem of commuters' choice of mode

Quaderno n. 01-01

M. Filippini, P. Prioni, The influence of ownership on the cost of bus service provision in Switzerland. An empirical illustration

Quaderno n. 01-02

B. Antonioli, M. Filippini, Optimal size in the waste collection sector

Quaderno n. 01-03

B. Schmitt, La double charge du service de la dette extérieure 
Quaderno n. 01-04

L. Crivelli, M. Filippini, D. Lunati, Regulation, ownership and efficiency in the Swiss nursing home industry

Quaderno n. 01-05

S. Banfi, L. Buchli, M. Filippini, Il valore ricreativo del fiume Ticino per i pescatori

Quaderno n. 01-06

L. Crivelli, M. Filippini, D. Lunati, Effizienz der Pflegeheime in der Schweiz

Quaderno n. 02-01

B. Antonioli, M. Filippini, The use of a variable cost function in the regulation of the Italian water industry

Quaderno n. 02-02

B. Antonioli, S. Banfi, M. Filippini, La deregolamentazione del mercato elettrico svizzero e implicazioni a breve termine per l'industria idroelettrica

Quaderno n. 02-03

M. Filippini, J. Wild, M. Kuenzle, Using stochastic frontier analysis for the access price regulation of electricity networks

Quaderno n. 02-04

G. Cassese, On the structure of finitely additive martingales

Quaderno n. 03-01

M. Filippini, M. Kuenzle, Analisi dell'efficienza di costo delle compagnie di bus italiane e svizzere

Quaderno n. 03-02

C. Cambini, M. Filippini, Competitive tendering and optimal size in the regional bus transportation industry

Quaderno n. 03-03

L. Crivelli, M. Filippini, Federalismo e sistema sanitario svizzero

Quaderno n. 03-04

L. Crivelli, M. Filippini, I. Mosca, Federalismo e spesa sanitaria regionale : analisi empirica per i Cantoni svizzeri

Quaderno n. 03-05

M. Farsi, M. Filippini, Regulation and measuring cost efficiency with panel data models : application to electricity distribution utilities

Quaderno n. 03-06

M. Farsi, M. Filippini, An empirical analysis of cost efficiency in non-profit and public nursing homes

Quaderno n. 03-07

F. Rossera, La distribuzione dei redditi e la loro imposizione fiscale : analisi dei dati fiscali svizzeri 
Quaderno n. 03-08

L. Crivelli, G. Domenighetti, M. Filippini, Federalism versus social citizenship : investigating the preference for equity in health care

Quaderno n. 03-09

M. Farsi, Changes in hospital quality after conversion in ownership status

Quaderno n. 03-10

G. Cozzi, O. Tarola, Mergers, innovations, and inequality

Quaderno n. 03-11

M. Farsi, M. Filippini, M. Kuenzle, Unobserved heterogeneity in stochastic cost frontier models : a comparative analysis

Quaderno n. 04-01

G. Cassese, An extension of conditional expectation to finitely additive measures

Quaderno n. 04-02

S. Demichelis, O. Tarola, The plant size problem and monopoly pricing

Quaderno n. 04-03

F. Rossera, Struttura dei salari 2000 : valutazioni in base all'inchiesta dell'Ufficio federale di statistica in Ticino

Quaderno n. 04-04

M. Filippini, M. Zola, Economies of scale and cost efficiency in the postal services : empirical evidence from Switzerland

Quaderno n. 04-05

F. Degeorge, F. Derrien, K.L. Womack, Quid pro quo in IPOs : why book-building is dominating auctions

Quaderno n. 04-06

M. Farsi, M. Filippini, W. Greene, Efficiency measurement in network industries : application to the Swiss railway companies

Quaderno n. 04-07

L. Crivelli, M. Filippini, I. Mosca, Federalism and regional health care expenditures : an empirical analysis for the Swiss cantons

Quaderno n. 04-08

S. Alberton, O. Gonzalez, Monitoring a trans-border labour market in view of liberalization: the case of Ticino

Quaderno n. 04-09

M. Filippini, G. Masiero, K. Moschetti, Regional differences in outpatient antibiotic consumption in Switzerland

Quaderno n. 04-10

A.S. Bergantino, S. Bolis, An adaptive conjoint analysis of freight service alternatives : evaluating the maritime option 
Quaderno n. 05-01

M. Farsi, M. Filippini, An analysis of efficiency and productivity in Swiss hospitals

Quaderno n. 05-02

M. Filippini, G. Masiero, K. Moschetti, Socioeconomic determinants of regional differences in outpatient antibiotic consumption : evidence from Switzerland

Quaderno n. 06-01

M. Farsi, L. Gitto, A statistical analysis of pain relief surgical operations

Quaderno n. 06-02

M. Farsi, G. Ridder, Estimating the out-of-hospital mortality rate using patient discharge data

Quaderno n. 06-03

S. Banfi, M. Farsi, M. Filippini, An empirical analysis of child care demand in Switzerland

Quaderno n. 06-04

L. Crivelli, M. Filippini, Regional public health care spending in Switzerland : an empirical analysis

Quaderno n. 06-05

M. Filippini, B. Lepori, Cost structure, economies of capacity utilization and scope in Swiss higher education institutions

Quaderno n. 06-06

M. Farsi, M. Filippini, Effects of ownership, subsidization and teaching activities on hospital costs in Switzerland

Quaderno n. 06-07

M. Filippini, G. Masiero, K. Moschetti, Small area variations and welfare loss in the use of antibiotics in the community

Quaderno n. 06-08

A. Tchipev, Intermediate products, specialization and the dynamics of wage inequality in the US

Quaderno n. 06-09

A. Tchipev, Technological change and outsourcing : competing or complementary explanations for the rising demand for skills during the 1980s?

Quaderno n. 07-01

M. Filippini, G. Masiero, K. Moschetti, Characteristics of demand for antibiotics in primary care : an almost ideal demand system approach

Quaderno n. 07-02

G. Masiero, M. Filippini, M. Ferech, H. Goossens, Determinants of outpatient antibiotic consumption in Europe : bacterial resistance and drug prescribers

Quaderno n. 07-03

R. Levaggi, F. Menoncin, Fiscal federalism, patient mobility and the soft budget constraint : a theoretical approach 
Quaderno n. 07-04

M. Farsi, The temporal variation of cost-efficiency in Switzerland's hospitals : an application of mixed models

Quaderno n. 08-01

M. Farsi, M. Filippini, D. Lunati, Economies of scale and efficiency measurement in Switzerland's nursing homes

Quaderno n. 08-02

A. Vaona, Inflation persistence, structural breaks and omitted variables : a critical view

Quaderno n. 08-03

A. Vaona, The sensitivity of non parametric misspecification tests to disturbance autocorrelation

Quaderno n. 08-04

A. Vaona, STATA tip : a quick trick to perform a Roy-Zellner test for poolability in STATA

Quaderno n. 08-05

A. Vaona, R. Patuelli, New empirical evidence on local financial development and growth

Quaderno n. 08-06

C. Grimpe, R. Patuelli, Knowledge production in nanomaterials : an application of spatial filtering to regional system of innovation

Quaderno n. 08-07

A. Vaona, G. Ascari, Regional inflation persistence : evidence from Italy

Quaderno n. 08-08

M. Filippini, G. Masiero, K. Moschetti, Dispensing practices and antibiotic use

Quaderno n. 08-09

T. Crossley, M. Jametti, Pension benefit insurance and pension plan portfolio choice 